\title{
Clinical Role of CYP2C19 Polymorphisms in Patients with Congenital Adrenal Hyperplasia Due to 21-hydroxylase Deficiency
}

\section{Urh Grošelj, ${ }^{1}$ Mojca Žerjav Tanšek, ${ }^{1}$ Katarina Trebušak Podkrajšek, ${ }^{2}$ Tinka Hovnik, ${ }^{2}$ Tadej Battelino ${ }^{1,3}$ and Vita Dolžan ${ }^{4, *}$}

${ }^{1}$ Department of Pediatric Endocrinology, Diabetes and Metabolic Diseases, University Children's Hospital, University Medical Centre Ljubljana, Ljubljana, Slovenia

${ }^{2}$ Center for Medical Genetics, University Children's Hospital, University Medical Centre Ljubljana, Ljubljana, Slovenia

${ }^{3}$ Department of Pediatrics, Faculty of Medicine, University of Ljubljana, Ljubljana, Slovenia

${ }^{4}$ Pharmacogenetics Laboratory, Institute of Biochemistry, Faculty of Medicine, University of Ljubljana, Ljubljana, Slovenia

* Corresponding author: E-mail: vita.dolzan @mf.uni-lj.si

Phone: +3961543 7670; Fax: +38615437641

Received: 20-07-2015

\begin{abstract}
Extraadrenal enzymes such as CYP2C19 may participate in residual 21-hydroxylation of progesterone leading to milder phenotypes of congenital adrenal hyperplasia (CAH) due to 21-hydroxylase deficiency (21OHD). Among 94 21OHD patients from the Slovene national registry 28 were homozygous or compound heterozygous for severe CYP21A2 mutations. We have reviewed their clinical phenotype and obtained information on maintenance doses of hydrocortisone and fludrocortisone. All patients were genotyped for $C Y P 2 C 19 * 2$ and $C Y P 2 C 19 * 17$ alleles. Among eleven patients with $C Y P 2 C 19 * 1 / * 17$ genotype, all had salt-wasting $210 H D$. Out of 17 patients with $C Y P 2 C 19$ genotypes leading to normal or decreased CYP2C19 activity, 15 had salt-wasting, one had simple virilizing and one had non-classical 21OHD. CYP $2 C 19 * 1 / * 17$ genotype was associated with lower maintenance dose of fludrocortisone $(\mathrm{p}=0.04)$, but not of hydrocortisone $(\mathrm{p}>0.05)$. Increased $C Y P 2 C 19$ activity could slightly ameliorate mineralocorticoid deficiency in 21OHD.
\end{abstract}

Keywords: CYP2C19, CYP21A2; 21-hydroxylase deficiency, congenital adrenal hyperplasia

\section{Introduction}

21-hydroxylase deficiency (21OHD) accounts for over $90 \%$ of cases of congenital adrenal hyperplasia $(\mathrm{CAH})$, a family of autosomal recessive disorders with an incidence of approximately $1 / 15.000 .{ }^{1} 21 \mathrm{OHD}$ is caused by CYP21A2 gene mutations that impair 21-hydroxylation of progesterone to deoxycorticosterone, a precursor of aldosterone, as well as the conversion of 17-hydroxyprogesterone to 11-deoxycortisol, the precursor of cortisol (Figure 1). ${ }^{2}$ The compensatory oversecretion of ACTH stimulates the synthesis of adrenal androgen precursors. Thus, clinical phenotype of $21 \mathrm{OHD}$ is characterized by the deficiency of aldosterone and/or cortisol, and by the excess of androgens.
In general, good correlation is observed between CYP21A2 genotype and 21OHD clinical phenotype. ${ }^{3}$ In salt-wasting (SW) 21OHD, usually manifesting early after birth with a salt-wasting crisis and with ambiguous external genitalia in girls, synthesis of both aldosterone and cortisol is impaired due to severe CYP21A2 mutations. In simple virilizing (SV) $21 \mathrm{OHD}$, manifesting with precocious pubarche and different degree of virilization of external genitalia in girls, only cortisol synthesis is deficient. In non-classical (NC) 21OHD the disease is mild and might not be detected until later in life.,

However, some patients with absent or functionally inactive 21-hydroxylase do not clinically present with the expected salt-wasting (SW) form of 210HD. ${ }^{6,7}$ Further- 


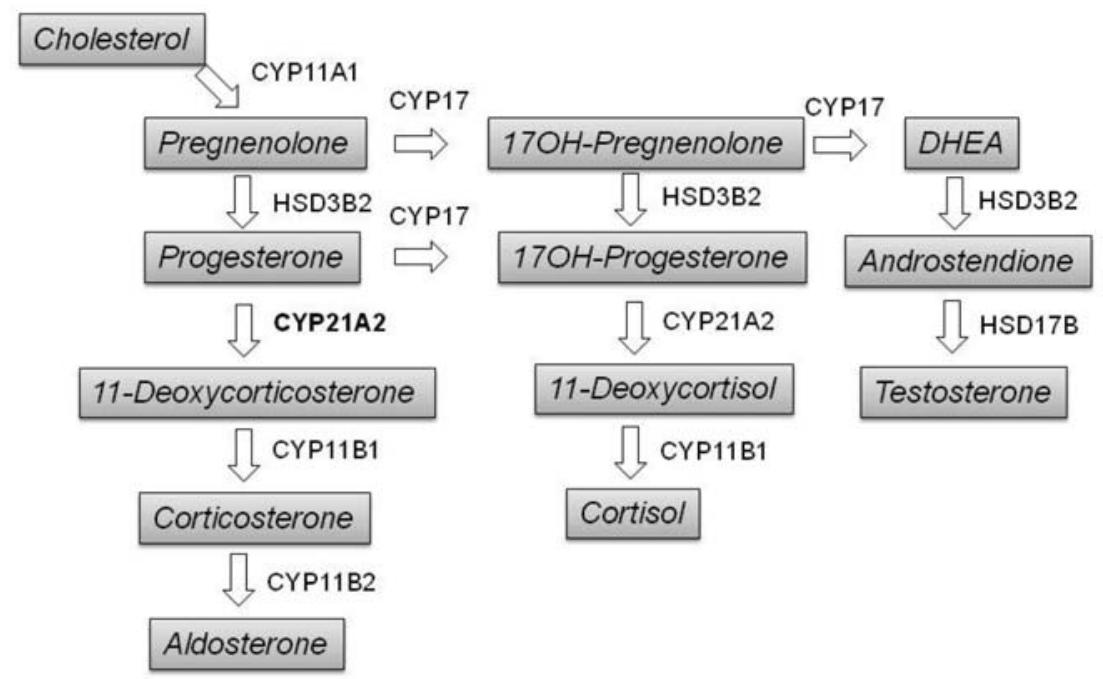

Figure 1. Synthesis of adrenal steroid hormones from cholesterol.

Legend: The step that can be augmented by extraadrenal hydoxylation via hepatic cytochrome P450 CYP2C19 is bolded. CYP11A1 - cholesterol side-chain cleavage enzyme; CYP17 - 17-alpha-hydroxylase / 17,20-lyase; HSD3B2 - 3ß-hydroxysteroid dehydrogenase; CYP21A2 steroid 21-hydroxylase; CYP11B1- steroid 11- $\beta$-hydroxylase; CYP11B2 - aldosterone synthase; 17 $\beta$-HSD - 17-beta-hydroxysteroid dehydrogenase.

more, some patients may regain their ability to retain salt over time, possibly also by increased activity of other 21hydroxylating enzymes. It has been shown that hepatic cytochrome P450 drug-metabolizing enzyme CYP2C19 can 21-hydroxylate progesterone but not 17-hydroxyprogesterone, possibly ameliorating mineralocorticoid deficiency, but not glucocorticoid deficiency. ${ }^{8,9}$ A large interindividual variability in CYP2C19 activity that is mainly determined by genetic polymorphisms of this enzyme has been observed. CYP $2 C 19 * 2$ allele accounts for $93 \%$ of the alleles that code for a non-functional enzyme in the Caucasians and in the Slovene population. ${ }^{10,11}$ A novel variant allele, $C Y P 2 C 19 * 17$ was reported to lead to ultra-rapid metabolism of some CYP2C19 substrates. It is characterized by two SNPs in the promoter region, $-3402 \mathrm{C}>\mathrm{T}$ and $-806 \mathrm{C}>\mathrm{T}$, the latter is associated with increased transcriptional activity that leads to ultra-rapid metabolism of some CYP2C19 substrates. ${ }^{12}$ CYP 2 C $19 * 17$ allele might thus increase the extraadrenal 21-hydroxylation of progesterone and synthesis of aldosterone. ${ }^{8}$

Our aims were to examine the influence of common CYP2C19 polymorphic alleles on clinical phenotype of 21OHD and on maintenance doses of hydrocortisone and fludrocortisone in $\mathrm{CAH}$ patients with severe $C Y P 21 A 2$ mutations.

\section{Experimental}

\section{1. Subjects}

From the Slovene national registry of 21-OHD patients all homozygous or compound heterozygous for se- vere $C Y P 21 A 2$ mutations, which were predicted to result in SW-21OHD, were selected. ${ }^{3}$ The registry is including all the known Slovenian patients with genetically confirmed 21-OHD, but it is possible that we have not captured all the 21-OHD patients in the population as Slovenia has not introduced a neonatal screening for 21-OHD yet.

Information on the clinical phenotype and the maintenance dose of fludrocortisone was obtained for all these patients from their medical records. Clinical diagnosis of different types of $210 H D$ was made by pediatric endocrinologists based on the history, physical examination, electrolyte and hormonal data. ${ }^{13}$ Patients with inadequate steroid hormone synthesis were defined as having SW$210 H D$ when clinical and laboratory signs of renal salt wasting were present in the first months of life, SV$210 H D$ when virilization appeared before the age of 4 years and NC-21OHD when the signs and symptoms of androgen excess became evident after the age of 4 years.

Written informed consent was obtained from all participants or their parents. The study was approved by the Slovene Medical Ethics Committee.

\section{2. Molecular Analysis of CYP21A2 Gene}

CYP21A2 genes of all 28 patients were analyzed as previously described. ${ }^{14,15}$ Southern blotting and/or sequence-specific PCR amplification (PCR-SSP) were used to detect large gene conversions and deletions, and sequence specific oligonucleotide hybridization (PCR-SSO) and/or sequencing was used to detect $C Y P 21 A 2$ gene point mutations. The results of molecular analyses of 24 out of 28 patients were previously reported. ${ }^{6,15}$ 


\section{3. Molecular Analysis of CYP2C19 Gene}

All the patients were genotyped for $C Y P 2 C 19 * 2$ (rs4244285) and $C Y P 2 C 19 * 17$ (rs12248560) alleles using TaqMan SNP genotyping assays on ABI 7500 Real Time PCR System (Applied Biosystems, Foster City, CA, USA), as previously described. ${ }^{16}$

\section{4. Statistical Analysis}

Statistical analysis was performed using WinSTAT 2007.1 for Excel (R. Fitch Software, Germany). Student's t-test was used to compare the maintenance doses of the hydrocortisone and of the fludrocortisone in the 21OHD patients with regard to the presence of CYP2C19 polymorphic alleles. The level of statistical significance was at $<0.05$.

\section{Results and Discussion}

In the cohort of 94 Slovene 21OHD subjects 28 patients from 25 families were homozygous or compound heterozygous for severe CYP21A2 mutations, predicted to result in SW-21OHD. Discordance between the genotype and the phenotype was found in 2 out of 28 patients with severe CYP21A2 mutations who were predicted to have SW-21OHD. The dates of birth of the patients ranged from 1971 to 2008. Clinical characteristics and CYP21A2 and $C Y P 2 C 19$ genotypes of all the included patients are shown in Table 1.

We examined the role of the CYP2C19 as a potential modifier gene contributing to the extraadrenal 21hydroxylation of the progesterone, possibly ameliorating the mineralocorticoid deficiency in 210HD. The

Table 1. Genetic and clinical characteristics of the patients

\begin{tabular}{|c|c|c|c|c|c|c|c|}
\hline No. & Sex & $\begin{array}{c}\text { Age } \\
\text { (years) }\end{array}$ & $\begin{array}{l}\text { CYP21A2 genotype } \\
\text { Allele } 1 \text { / Allele } 2\end{array}$ & $\begin{array}{c}\text { 21OHD } \\
\text { phenotype }\end{array}$ & $\begin{array}{l}\text { Virilization } \\
\text { in females }\end{array}$ & $\begin{array}{l}\text { CYP2C19 } \\
\text { genotype }\end{array}$ & $\begin{array}{l}\text { CYP2C19 } \\
\text { phenotype }\end{array}$ \\
\hline$\overline{1}$ & $\mathrm{M}$ & 35 & Del / Del & SW & & $* 1 / * 17$ & UM \\
\hline 2 & $\mathrm{~F}$ & 2 & Del / Del & SW & $\mathrm{CM}$ & $* 1 / * 17$ & UM \\
\hline 3 & $\mathrm{~F}$ & 20 & Del / Conv + Ala15Thr + Pro30Leu & SW & $\mathrm{CM}$ & $* 1 / * 17$ & UM \\
\hline 4 & $\mathrm{~F}$ & 16 & Del / Conv + Ala15Thr + Pro30Leu & SW & $\mathrm{CM}$ & $* 1 / * 17$ & UM \\
\hline 5 & $\mathrm{~F}$ & 31 & Del de novo / Large conv & SW & SU & $* 1 / * 17$ & UM \\
\hline 6 & $\mathrm{~F}$ & 39 & Del / In2 & SW & SU & $* 1 / * 17$ & UM \\
\hline 7 & M & 9 & Del / In2 & SW & & $* 1 / * 17$ & UM \\
\hline 8 & $\mathrm{~F}$ & 22 & Del / In2 & SW & SU & $* 1 / * 17$ & UM \\
\hline 9 & M & 5 & $\operatorname{In} 2 / \operatorname{In} 2+$ Gln318Stop & SW & & $* 1 / * 17$ & UM \\
\hline 10 & $\mathrm{~F}$ & 3 & In 2 / Prom conv + del $8 b p$ ex 3 & SW & $\mathrm{CM}$ & $* 1 / * 17$ & UM \\
\hline 11 & M & 4 & $\operatorname{In} 2 / \operatorname{In} 2$ & SW & & $* 1 / * 17$ & UM \\
\hline 12 & M & 23 & Del / Del & SW & & $* 2 / * 17$ & EM \\
\hline 13 & $\mathrm{M}$ & 34 & Del / Del & SW & & $* 1 / * 1$ & EM \\
\hline 14 & $\mathrm{~F}$ & 22 & Del / Del & SW & SU & $* 1 / * 1$ & EM \\
\hline 15 & $\mathrm{~F}$ & 15 & Del / Del & SW & SU & $* 2 / * 17$ & EM \\
\hline 16 & $\mathrm{~F}$ & 34 & Large conv / Del & SW & SU & $* 1 / * 1$ & EM \\
\hline 17 & $\mathrm{~F}$ & 37 & Del / Gln318Stop & SW/NC & & $* 1 / * 1$ & $\mathrm{EM}$ \\
\hline 18 & $\mathrm{~F}$ & 33 & Del / InsT307+ Gln318Stop & SW & SU & $* 1 / * 1$ & $\mathrm{EM}$ \\
\hline 19 & M & 14 & InsT307 + Gln318Stop / & SW & & $* 2 / * 17$ & EM \\
\hline 20 & M & 12 & $\begin{array}{l}\text { InsT307 + Gln318Stop / In2 + Ex6 } \\
\text { + Val281Leu + Gln318Stop }\end{array}$ & SW & & $* 2 / * 17$ & $\mathrm{EM}$ \\
\hline 21 & $\mathrm{M}$ & 36 & Del / Conv + Pro30Leu & SW/SV & & $* 1 / * 1$ & $\mathrm{EM}$ \\
\hline 22 & M & 3 & Del / In2 & SW & & $* 1 / * 2$ & IM \\
\hline 23 & $\mathrm{M}$ & 5 & Del / In2 + Val281Leu & SW & & $* 1 / * 1$ & $\mathrm{EM}$ \\
\hline 24 & M & 8 & In 2 / Ile172Asn + Ex6 + Pro453Ser & SW & & $* 1 / * 1$ & EM \\
\hline 25 & M & 26 & In $2 /$ In $2+$ Pro 453 Ser & SW & & $* 2 / * 17$ & EM \\
\hline 26 & M & 21 & $\operatorname{In} 2 / \operatorname{In} 2+$ Pro453Ser & SW & & $* 2 / * 17$ & $\mathrm{EM}$ \\
\hline 27 & $\mathrm{~F}$ & 19 & $\operatorname{In} 2 / \operatorname{In} 2$ & SW & SU & $* 1 / * 1$ & EM \\
\hline 28 & $\mathrm{~F}$ & 21 & $\operatorname{In} 2 / \operatorname{In} 2$ & SW & SU & $* 1 / * 1$ & EM \\
\hline
\end{tabular}

Legend: No.: Patient number; Sex: F, female; M, male. Age: age at the inclusion in the study. CYP21A2 Alleles: Del, CYP21A2 gene deletion; Large conv, large CYP21A2 gene conversion; In2, intron 2 splice mutation. 21OHD phenotype: SW, salt wasting; SV, simple virilising; NC, non-classical. Virilisation in females: CM, clitoromegaly; SU, sinus urogenitalis. CYP2C19 genotype: *1, wild type; *2, decreased activity allele; *17, ultra-rapid activity allele. CYP2C19 phenotype: UM, ultrarapid metabolizer; EM, extensive metabolizer; IM, intermediate metabolizer. 
CYP2C19 genotype distribution was: $* 1 / * 135.7 \%, * 1 / * 2$ $3.6 \%, * 1 / * 1739.3 \%$ and $* 2 / * 1721.4 \%$. The high frequency of the $C Y P 2 C 19 * 17$ allele (genotypes $* 1 / * 17$ or $* 2 / * 17$ ) observed in the $210 \mathrm{OHD}$ patients was in agreement with the previous reports on the CYP2C19 allele frequency in the Slovene population. ${ }^{16}$ However, no homozygotes for the $C Y P 2 C 19 * 17$ were found in our patient group. We have not analyzed other variant $C Y P 2 C 19$ alleles in our study. $C Y P 2 C 19^{*} 17$ is the only allele with confirmed association with increased enzyme activity. ${ }^{12}$ Among the other non-functional alleles, CYP2C19*3 is very rare in Caucasians and as confirmed by our previous study, also very rare ( $0.4 \%$ allele frequency) in Slovenian population. ${ }^{11}$

All the 11 patients with $C Y P 2 C 19 * 1 / * 17$ genotype, that could possibly lead to an increased CYP2C19 metabolic capacity for substrate hydroxylation, ${ }^{8}$ had SW21OHD. Among 17 patients with other CYP2C19 genotypes leading to normal $(* 1 / * 1$ and $* 2 / * 17)$ or decreased $(* 1 / * 2)$ CYP2C19 enzyme activity, 15 had SW-21OHD, one had SV-21OHD and one had NC-21OHD. This data indicates that $C Y P 2 C 19 * 1 / * 17$ genotype did probably not influence the clinical phenotype of 21OHD. This is in concordance with the previously reported observations that heterozygosity for $C Y P 2 C 19 * 17$ is insufficient to modulate the clinical phenotype of SW-21OHD. ${ }^{8}$ In the group with $C Y P 2 C 19 * 1 / * 17$ genotype the average maintenance dose of hydrocortisone was $16.6 \mathrm{mg} / \mathrm{m}^{2}$ as compared to $17.7 \mathrm{mg} / \mathrm{m}^{2}$ in group with other $C Y P 2 C 19$ genotypes $(\mathrm{p}>0.05)$. However, the average maintenance dose of fludrocortisone was $0.057 \mathrm{mg} /$ day in the first group as compared to $0.075 \mathrm{mg} /$ day in the later group $(\mathrm{p}=0.04)$, suggesting a possibility of subtle modification of mineralocorticoid, but not glucocorticoid requirement by CYP2C19 genotype.

We have performed an additional statistical analysis on 22 non-related patients that remained after the exclusion of the three pairs of sibling. The effect of $C Y P 2 C 19 * 1 / * 17$ genotype remained significant as the average maintenance dose of fludrocortisone was 0.056 $\mathrm{mg} /$ day in the first group as compared to $0.084 \mathrm{mg} /$ day in the latter group $(\mathrm{p}=0.02)$. Our results are consistent with reports that CYP2C19 can 21-hydroxylate progesterone but not 17-hydroxyprogesterone, thus possibly ameliorating the mineralocorticoid deficiency, but not the glucocorticoid deficiency. ${ }^{8,9}$

Other modifier genes that were not accounted for in our study may contribute to the observed 21OHD genotype phenotype inconsistencies as it is possible that other enzymes contribute to extra-adrenal 21-hydroxylation. Besides CYP2C19, CYP3A4 was reported to 21-hydroxylate progesterone, but not 17-hydroxyprogesterone. Although the affinity of CYP3A4 for progesterone was approximately 10 -fold lower compared to CYP2C19, it should be noted that CYP3A4 is the most abundant cytochrome P450 drug metabolizing enzyme in the liver. ${ }^{8}$
Functional variants in the CYP3A4 gene that may have functional effect have been characterized, but they are rare in Caucasian population. ${ }^{17}$ One of the most common functional variants, $C Y P 3 A 4 * 22$ allele that leads to decreased enzyme activity has a frequency of $5-7 \%$ in Caucasian populations. ${ }^{18}$ Therefor we would need a much larger sample to investigate the potential role of this polymorphism in 21OHD genotype - phenotype inconsistency.

\section{Conclusions}

Our results suggest that the $C Y P 2 C 19 * 1 / * 17$ genotype could possibly lead to a very subtle modification of clinical phenotype of 21OHD. The average maintenance dose of fludrocortisone was slightly, although significantly lower in patients with $C Y P 2 C 19 * 1 / * 17$ genotype as compared to patients with other $C Y P 2 C 19$ genotypes. On the other hand, the average maintenance dose of hydrocortisone did not differ significantly between the both groups of patients, which is concordant with previous suggestions. ${ }^{8}$ Nevertheless, our observations are based on a low number of patients and should be independently validated in a larger cohort of patients with prospectively collected clinical data. Namely, an important limitation of our study is that the data collection was performed retrospectively. However, the main strength of our study is the novel approach, translating the interesting basic findings into the clinical practice with the aim to elucidate the clinical role of possible modifier genes.

CONFLICTS OF INTEREST: None declared.

FUNDING: The study was supported in part by the Slovenian National Research Agency grants P1-0170 and P30343.

ETHICAL APPROVAL: Written informed consent was obtained from all participants or their parents. The study was approved by the Slovene Medical Ethics Committee.

\section{References}

1. B. L. Therrell, Jr., S. A. Berenbaum, V. Manter-Kapanke, J. Simmank, K. Korman, L. Prentice, et al, Pediatrics 1998, 101, 583-590. http://dx.doi.org/10.1542/peds.101.4.583

2. P. W. Speiser, P. C. White, N. Engl. J. Med. 2003, 349, 776788. http://dx.doi.org/10.1056/NEJMra021561

3. N. Krone, A. Braun, A. A. Roscher, D. Knorr, H.P. Schwarz, J. Clin. Endocrinol. Metab. 2000, 85, 1059-1065. http://dx.doi.org/10.1210/jcem.85.3.6441

4. P. W. Speiser, J. Dupont, D. Zhu, J. Serrat, M. Buegeleisen, M. T. Tusie-Luna, et al., J. Clin. Invest. 1992, 90, 584-595. http://dx.doi.org/10.1172/JCI115897

5. P. C. White, M. I. New, J. Clin. Endocrinol. Metab. 1992, 74, 6-11. 
6. V. Dolzan, J. Solyom, G. Fekete, J. Kovacs, V. Rakosnikova, F. Votava, et al., Eur. J. Endocrinol. 2005, 153, 99-106. http://dx.doi.org/10.1530/eje.1.01944

7. R. C. Wilson, A. B. Mercado, K. C. Cheng, M. I. New, J. Clin. Endocrinol. Metab. 1995, 80, 2322-2329.

8. L. G. Gomes, N. Huang, V. Agrawal, B. B. Mendonca, T. A. Bachega, W. L. Miller, J. Clin. Endocrinol. Metab. 2009, 94, 89-95. http://dx.doi.org/10.1210/jc.2008-1174

9. H. Yamazaki, T. Shimada, Arch. Biochem. Biophys. 1997, 346, 161-169. http://dx.doi.org/10.1006/abbi.1997.0302

10. S. M. de Morais, G. R. Wilkinson, J. Blaisdell, K. Nakamura, U. A. Meyer, J. A. Goldstein, J. Biol. Chem. 1994, 269, 15419-15422.

11. D. Herman, V. Dolzan, K. Breskvar, Zdrav. Vestn. 2003, 72, 347-351.

12. S. C. Sim, C. Risinger, M. L. Dahl, E. Aklillu, M. Christensen, L. Bertilsson, et al., Clin. Pharmacol. Ther. 2006, 79, 103-113. http://dx.doi.org/10.1016/j.clpt.2005.10.002
13. M. I. New, F. Lorenzen, A. J. Lerner, B. Kohn, S. E. Oberfield, M. S. Pollack, et al., J. Clin. Endocrinol. Metab. 1983, 57, 320-326. http://dx.doi.org/10.1210/jcem-57-2-320

14. V. Dolzan, J. Prezelj, B. Vidan-Jeras, K. Breskvar, Eur. J. Endocrinol. 1999, 141, 132-139. http://dx.doi.org/10.1530/eje.0.1410132

15. V. Dolzan, M. Stopar-Obreza, M. Zerjav-Tansek, K. Breskvar, C. Krzisnik, T. Battelino, Eur. J. Endocrinol. 2003, 149, 137-144. http://dx.doi.org/10.1530/eje.0.1490137

16. P. Bohanec Grabar, B. Rozman, M. Tomsic, D. Suput, D. Logar, V. Dolzan, Eur. J. Clin. Pharmacol. 2008, 64, 871-876. http://dx.doi.org/10.1007/s00228-008-0498-2

17. A. N. Werk, I. Cascorbi. Clin Pharmacol Ther. 2014, 96, 340-348. http://dx.doi.org/10.1038/clpt.2014.129

18. L. Elens, T. van Gelder, D. A. Hesselink, V. Haufroid, R. H. van Schaik. Pharmacogenomics 2013, 14, 47-62. http://dx.doi.org/10.2217/pgs.12.187

\section{Povzetek}

Progesteron se v manjši meri lahko na mestu 21 hidroksilira tudi izven nadledvične žleze, na primer s CYP2C19 v jetrih. To bi lahko vodilo v milejši fenotip kongenitalne adrenalne hiperplazije (CAH) zaradi pomanjkanja 21-hidroksilaze (21OHD). V slovenskem nacionalnem registru je bilo med 94 bolniki z 21OHD 28 homozigotov ali sestavljenih heterozigotov za hude mutacije CYP21A2. Preverili smo njihov klinični fenotip, pridobili podatke o vzdrževalnih odmerkih hidrokortizona in fludrokortizona in z genotipizacijo preverili prisotnost alelov $C Y P 2 C 19 * 2$ in $C Y P 2 C 19 * 17$. Vseh enajst bolnikov z genotipom $C Y P 2 C 19 * 1 / * 17$ je imelo $210 H D$ z izgubljanjem soli. Od 17 bolnikov z genotipi CYP2C19, povezanimi z normalno ali zmanjšano aktivnostjo CYP2C19, jih je imelo $15210 \mathrm{HD}$ z izgubljanjem soli, eden je imel OHD s preprosto virilizacijo, eden pa neklasično obliko bolezni. Genotip CYP2C19*1/*17 je bil povezan z nižjimi vzdrževalnimi odmerki fludrokortizona $(p=0,04)$, ne pa tudi hidrokortizona $(p>0,05)$. Povečana aktivnost CYP2C19 bi lahko nekoliko omilila pomanjkanje mineralokortikoidov pri $210 H D$. 